\title{
Some like it cold: populations of the tellinid bivalve Macoma balthica (L.) suffer in various ways from a warming climate
}

\author{
J. J. Beukema ${ }^{1, *}$, R. Dekker ${ }^{1}$, J. M. Jansen ${ }^{2}$ \\ ${ }^{1}$ Royal Netherlands Institute for Sea Research (NIOZ), PO Box 59, Den Burg, Texel, The Netherlands \\ ${ }^{2}$ Wageningen Institute for Marine Resources and Ecosystem Studies (IMARES), Korringaweg 5, 4401 NT, Yerseke, \\ The Netherlands
}

\begin{abstract}
Because of its relatively low tolerance to elevated temperatures, Macoma balthica (L.) may be one of the first important marine species in temperate coastal areas to suffer from a warming climate. For the last few decades, the abundance of the species in the Dutch Wadden Sea has been seriously declining. At lower latitudes, the southern edge of its range recently shifted several $100 \mathrm{~s}$ of $\mathrm{km}$ to the north. To understand changes in abundance related to high temperatures, we studied short-term population responses to warmer than average seasons using data from a long-term $(>35 \mathrm{yr}$ ) sampling program in the western Wadden Sea. The observed relationships included reduction of reproductive output and recruitment in years starting with mild winter-spring periods, reduction of adult survival in years with warm summers, reduction of annual migration in $\sim 8$ mo olds to more favourable areas in mild winters, reduction of growth rates in warmer than average growing seasons, and enhancement of seasonal weight loss in milder than average winters. We conclude that elevated temperatures negatively affect population dynamics of $M$. balthica in a number of ways, i.e. via recruitment or mortality as well as growth. These negative influences were observed already far below the upper lethal temperature of the species and in populations living $\sim 1000 \mathrm{~km}$ poleward of the warm edge of the species' range. The outcome of $M$. balthica's energy balance appears to be decisive for their continued existence by effects not only on individual weights but also on mortality as well as reproduction.
\end{abstract}

KEY WORDS: Bivalve population dynamics $\cdot$ Climate change $\cdot$ Water temperature $\cdot$ Recruitment Mortality $\cdot$ Migration $\cdot$ Weight changes $\cdot$ Wadden Sea

\section{INTRODUCTION}

In line with the presently warming global climate, seawater temperatures show substantially increasing trends in (sub)polar and temperate climatic zones. Along the North Sea coasts, rises in temperature were particularly steep in the last 20 yr. Currently, mean annual seawater temperatures along the Dutch North Sea coast are $>1^{\circ} \mathrm{C}$ higher than 2 decades ago and such increasing trends have been observed across all seasons (van Aken 2008). Similar temperature rises have been observed elsewhere at temperate latitudes, resulting in increasing abundance of lower-latitude species (southern species in the Northern Hemisphere) and declines in higher-latitude species (e.g. Barry et al. 1995). At temperate latitudes, a temperature rise of $\sim 1^{\circ} \mathrm{C}$ results in a poleward shift in climate zones of 100s of $\mathrm{km}$. Such a change would be of sufficient magnitude to affect animal populations over extensive areas (Root et al. 2003). Long-term monitoring results indicate a recent poleward shift of intertidal biota by $\sim 50 \mathrm{~km}$ per decade (Helmuth et al. 2006). In the low-latitude (warm) part of a species range, this may ultimately lead to local extirpation. Further long-term temperature increases are expected (Houghton 2001, IPCC 2007).

To identify mechanisms underlying poleward changes in species ranges as a consequence of global warming, it will be fruitful to study population responses to incidental warmer than average summers and milder than average winters. Such studies should be of a long-term 
nature and include not only long-term assessments of the total size of the population, but also the main processes leading to changes in population size: recruitment, survival, and migration. Additional experimental studies at the organism level can provide insight into the underlying physiological base of population processes, in particular the influence of temperature on rates of food consumption and energy expenditure, together determining the energy balance.

The present study reviews our knowledge with reference to these topics in one species: the tellinid bivalve Macoma balthica (L.). This is a suitable species, because many details are known on its physiology and ecology, both from the numerous published studies and from results of a long-term (almost $40 \mathrm{yr}$ ) monitoring program of the population dynamics of the zoobenthos at Balgzand, a tidal-flat area in the western part of the Wadden Sea. In addition to reviewing already published data, portions of a long-term dataset on the M. balthica population at Balgzand are presented and used to study how population dynamics and growth rates of this species are related to seasonal temperatures.

Among the abundant species of Wadden Sea bivalves, Macoma balthica is the most limited in its distribution towards low latitudes. Among these species (including Cerastoderma edule, Crassostrea gigas, Mya arenaria, and Mytilus edulis), M. balthica is also the most sensitive to high temperatures: the upper and lower boundary of the range of tolerated temperatures as well as its optimal temperature were found to be lower than those of these other bivalve species in the Wadden Sea, as shown in comparative studies by van der Veer et al. (2006), Freitas et al. (2007), and Jansen et al. (2007b). Its relatively high sensitivity to elevated ambient temperatures is the main reason why it was chosen for the present study: it may be one of the first to suffer and disappear from a substantial part of its present range as a consequence of a warming climate. Over nearly all of the Dutch Wadden Sea, M. balthica abundance has seriously declined for the past 1 or 2 decades (Dekker \& Beukema 2007, Dekker \& Waasdorp 2008, J. M. Jansen pers. obs., see Fig. 1b), but it remains to be seen whether this decrease can be fully attributed to the consequences of rising temperatures.

The aim of the present study is to review the available evidence for temperature-related changes in Macoma balthica populations living in the low-latitude (warm) half of the species' range. We hypothesize negative effects of higher than average seasonal temperatures including (1) lower recruitment (Beukema et al. 2001a, Strasser et al. 2003) and (2) lower survival in years with relatively high temperatures in one or more seasons, and (3) more severe and lengthy periods of negative energy balance (De Wilde 1975, Hummel $1985 b$ ) in such years. We further discuss observed changes in distribution patterns, including a poleward range shift (Barry et al. 1995, Jansen et al. 2007a) and (at smaller scales) shifts to deeper waters to escape excessive heating (Wilson 1990), and phenological changes such as earlier starting dates in spring of seasonal processes (Philippart et al. 2003, Root et al. 2003).

\section{MATERIALS AND METHODS}

Species. At present, the original Macoma balthica (L.) species complex is no longer regarded as one single species. In accordance with Väinölä (2003) and Nikula et al. (2007), the populations of the southern temperate part of the West Atlantic are considered a separate species: Macoma petalum (Valenciennes). Within the remaining northerly circumpolar complex, 2 subspecies can be distinguished: (1) a mainly North Pacific subspecies, Macoma balthica balthica, with European populations inhabiting the White Sea and Baltic Sea; and (2) a northeastern Atlantic subspecies, Macoma balthica rubra, found along the North Sea and northeast Atlantic coasts (Norway, UK, and France). The present study is restricted to the $M$. balthica rubra subspecies, which most likely originates from invasions from the Arctic basin to more southern latitudes about 2 million yr ago (Nikula et al. 2007).

Monitoring data. In addition to published results, a number of unpublished data from the Balgzand monitoring program will be presented. Since $\sim 1970$, macrozoobenthos samples have been taken twice annually at 15 fixed stations at tidal flats in the westernmost part of the Wadden Sea at $\sim 53^{\circ} \mathrm{N}, 6^{\circ} \mathrm{E}$ (see Beukema \& Cadée 1997 for details on location and environmental conditions of the sampling stations). These stations cover the entire tidal range (mean range from 60 to $-80 \mathrm{~cm}$ relative to mean-tide level) and almost all sediment types. Sampling procedures are explained in Dekker \& Beukema (2007). In short, the samples were sieved in the field over $1 \mathrm{~mm}$ sieves and sorted alive in the laboratory. Macoma balthica individuals were sorted to year of birth, counted, and their greatest shell length was measured. The ash-free dry mass (AFDM) of their soft parts was determined as the difference in weight after drying to constant weight at $60^{\circ} \mathrm{C}$ and subsequent ashing at $\sim 560^{\circ} \mathrm{C}$.

Annual data from the Balgzand monitoring program were available for 35 to 39 successive years of the 1969-2007 period (late-winter samplings, mostly in March, and late-summer samplings, mostly in August). These data refer to numerical densities (ind. $\mathrm{m}^{-2}$ ), biomass ( $\mathrm{g}$ AFDM m $\mathrm{m}^{-2}$ ), individual lengths and weights 
(allowing estimates of condition as a body-mass index [BMI]: individual AFDM divided by third power of shell length, in $\mathrm{mg} \mathrm{cm}^{-3}$ ), and allocation of each individual to a cohort (year of birth, from annual shell marks), allowing estimates of annual growth (as 15station means of mean individual AFDM change between March and August in individuals belonging to the age-group of $\sim 1$ yr olds), recruitment (as 15-station means of numerical densities of 0-group animals in August), and mortality. Mortality is expressed as $z$ $\left(\mathrm{d}^{-1}\right)$, i.e. the natural $\log (\mathrm{ln})$ of the quotient of the number of adults $\mathrm{m}^{-2}$ of adults at the start $\left(\mathrm{N}_{\mathrm{o}}\right)$ and end $\left(\mathrm{N}_{t}\right)$ of the period divided by the number of days $(t)$ elapsed between the 15-station mean dates of the samplings at the start and end of the period, $z=\ln \left(\mathrm{N}_{\mathrm{o}} / \mathrm{N}_{t}\right) / t$. Some of the basic data series on the population of Macoma balthica on Balgzand have been assembled in Fig. 1, showing long-term changes in biomass, annual recruitment, annual mortality, seasonal weight gain, and seasonal weight loss.

Temperature records. Monthly temperature values have been derived from daily observations (at 08:00 h) of surface water temperatures from a jetty at the shore of the Marsdiep tidal inlet (the main tidal inlet of the westernmost part of the Dutch Wadden Sea) at $<10 \mathrm{~km}$ from Balgzand (data are summarized in van Aken 2008). In all seasons, water temperatures showed significantly increasing trends for the past 2 decades (those for winter and summer temperatures are shown, Fig. 1a).

Statistics and data selection. To evaluate statistical significance, both non-parametric (sign test) and parametric tests (best linear fits of correlated data) were applied. In the latter tests, some obvious outliers (i.e. values $>2.5 \mathrm{SD}$ away from the average) were omitted from the calculations. The 37 annual values for recruit densities included one outlying value (see Figs. 1c \& 2a). As to mortality rates, 8 such data points (out of 37 ) were present: an exceptionally low one for 1976 and 7 successive exceptionally high rates in the early 2000s (see Figs. 1d \& 3). The low 1976 point may have been due to sampling error, but the 7 high points were not random outliers. The temporarily elevated mortality rates for the 1999-2006 period was caused by a temporarily effective extra cause of mortality, most likely the presence of a parasite, as argued by J. Drent et al. (unpubl. data).

In the calculations of mean late-winter BMI values, data from one or more stations had to be omitted in some years because of a late sampling date (in April instead of February or March). In a few years, even some late-March data had to be omitted because growth had started already in March, resulting in rapidly rising BMI values; this was particularly so in 1991 (Beukema \& Cadée 1996, their Fig. 3).

\section{RESULTS}

\section{Recruitment}

Densities of Macoma balthica recruits (ind. $\mathrm{m}^{-2}$ of early benthic life stages as assessed $\sim 3$ mo after their settlement on the tidal flats) showed high year-to-year variability (Fig. 1c). Recruit densities were on average significantly higher in years starting with a cold than with a mild winter (Fig. 2a). Even if the one outlier in Fig. 2a (i.e. the extremely successful recruitment in 1991) is included, the negative relationship between winter water temperature and subsequent recruitment remains statistically significant ( $p<0.05)$.

As cold winters lead to cold springs in this area (van Aken 2008), negative relationships between water temperature and recruitment-as shown in Fig. 2a from December to February - are to be expected and were indeed found for each of the 6 mo of the January-June period (most were statistically significant). Therefore, it is difficult to determine in which part of the first half of the year the subsequent success or failure of recruitment was actually established.

Recruitment was not very successful $\left(<300 \mathrm{~m}^{-2}\right)$ in all of the years starting with a mean winter water temperature of $>4^{\circ} \mathrm{C}$ (Fig. 2a). Colder winters were rather frequent before 1988, but rare after this year (Fig. 1a). Highly successful recruitment $\left(>300 \mathrm{~m}^{-2}\right)$ did not occur in any of the 16 years after 1991.

\section{Mortality}

Up to the year 2000, the Balgzand population of Macoma balthica showed relatively low and constant mortality rates (Fig. 1d). Subsequently, mortality rates suddenly increased sharply and remained high for a period of $\sim 7 \mathrm{yr}$. Because these 7 values were true outliers (see 'Materials and methods'), they will be ignored in the following analyses.

Annual mortality rates were significantly higher in years including a warm summer than in years characterized by a cold summer (Fig. 3a). Winter temperature within the year of observation, on the other hand, did not show any correlation with annual mortality ( $p$ > 0.9) (Fig. 3b).

Mortality rates were not equal in all seasons. On average, they were significantly higher in spring-summer (March to August) than in autumn-winter (August to $\mathrm{March}$ ) (mean $\pm \mathrm{SE}=0.0027 \pm 0.0003$ versus 0.0011 $\pm 0.0001 \mathrm{~d}^{-1}$, respectively, $\mathrm{p}<0.001$, sign test for differences between 35 paired values). Thus, even a slight temperature effect on the relatively high rates of spring-summer mortality would potentially contribute more to variability in annual mortality than a possible 

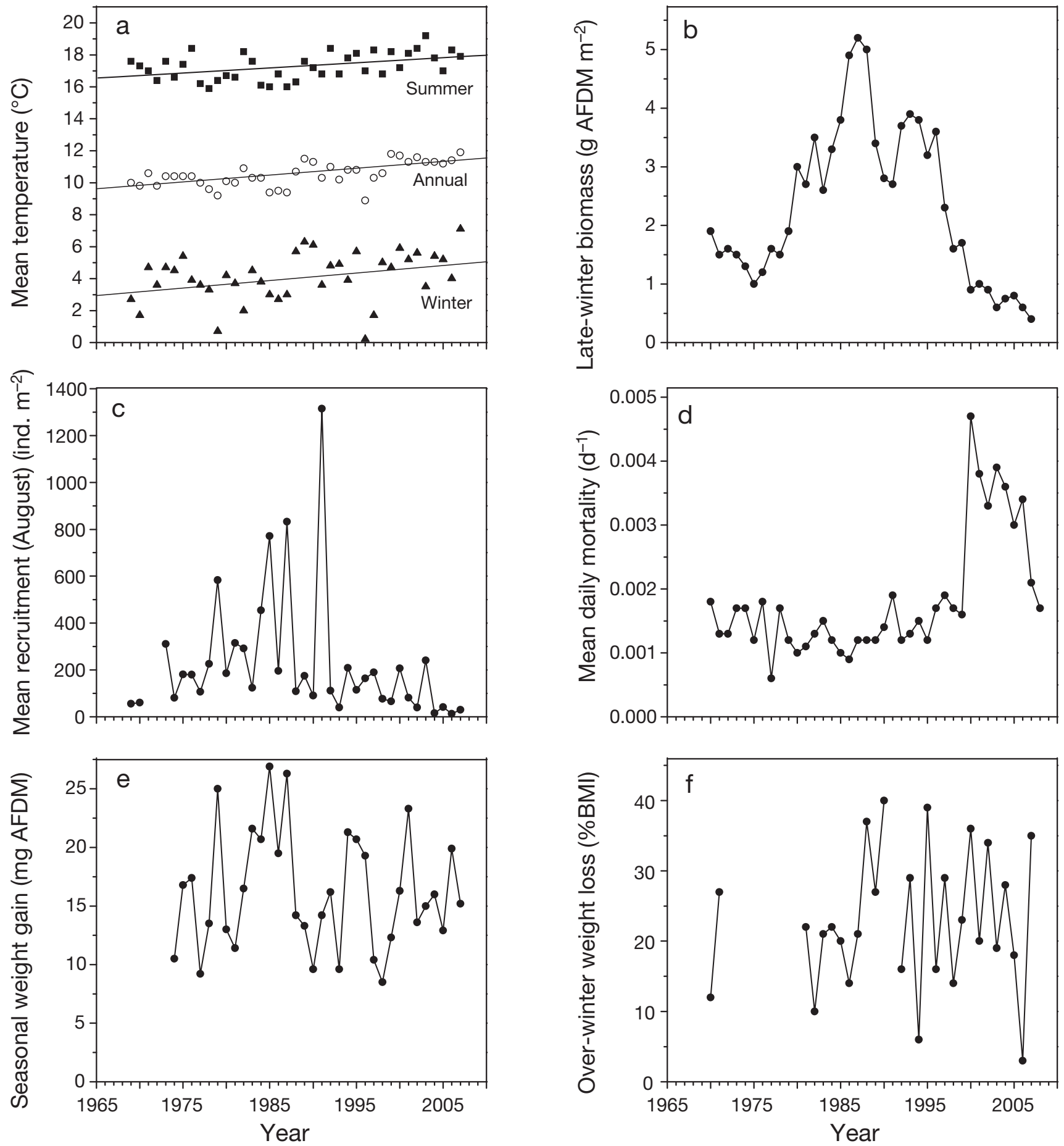

Fig. 1. Macoma balthica. Long-term data series for water temperatures in Marsdiep tidal inlet (courtesy H. van Aken, NIOZ) and 5 parameters of the $M$. balthica population on Balgzand tidal flats, based on twice-annual sampling at 15 stations. (a) Mean water temperatures $\left({ }^{\circ} \mathrm{C}\right)$ : $\boldsymbol{\Delta}$ winter (Dec-Feb average), O annual, $\boldsymbol{\square}$ summer (Jun-Aug average). (b) Late-winter total (sums of all age groups) biomass in $\mathrm{g}$ ash free dry mass (AFDM) $\mathrm{m}^{-2}$. (c) Late-summer estimates of density of recruits (young of the year) (ind. $\mathrm{m}^{-2}$ ). (d) Annual mortality of adults ( $>1$ yr olds) between 2 successive late-winter samplings (mean instantaneous daily rate) $\left(\mathrm{d}^{-1}\right)$. (e) Mean individual weight gain of soft body parts between late winter and subsequent late summer of $\sim 1 \mathrm{yr}$ olds (mg AFDM ind. ${ }^{-1}$ ). (f) Proportions of late-summer weights (as \% body mass index [BMI] of August values) lost between late-summer and latewinter samplings for $\sim 1.5 \mathrm{yr}$ olds. Linear trends shown only if statistically significant over entire period: (a) mean temperatures $(\mathrm{n}=39)$ annual $=-71.0+0.041 \times$ year $(\mathrm{r}=0.61, \mathrm{p}<0.0001)$; summer $=-46.5+0.032 \times$ year $(\mathrm{r}=0.44, \mathrm{p}<0.01)$; winter $=-88.6+$ 

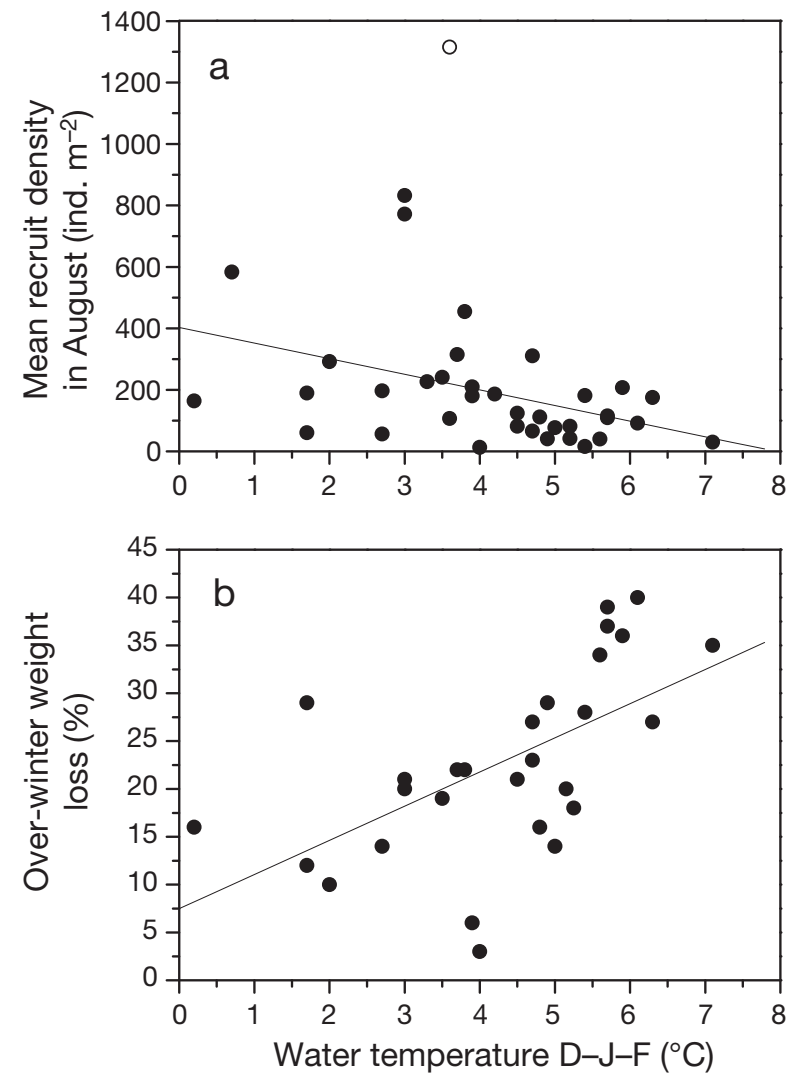

Fig. 2. Macoma balthica. Relationships between winter water temperatures (Dec-Feb average in Marsdiep tidal inlet, ${ }^{\circ} \mathrm{C}$ ) and (a) subsequent estimates of mean densities of recruits on Balgzand in August (means of 15 fixed sampling stations, ind. $\mathrm{m}^{-2}$ ), and (b) Loss of soft-body weight of $\sim 1.5 \mathrm{yr}$ olds (as $\%$ BMI of August values) in the August-March half-year period that included the winter of the plotted temperature. (O): outlier. Best linear fits: (a) recruit density $=407-51 \times$ temperature $(\mathrm{r}=-0.42, \mathrm{n}=36, \mathrm{p}=0.01)$, and $(\mathrm{b}) \% \mathrm{BMI}=7.5+3.57$ $\times$ temperature $(\mathrm{r}=0.59, \mathrm{n}=28, \mathrm{p}<0.005)$

temperature influence of a similar magnitude on the relatively low autumn-winter rates. Actually, temperatures were found to significantly affect mortality in both half-year periods: mortality rates in spring-summer were positively correlated with temperature $(\mathrm{r}=$ $0.51, \mathrm{n}=28, \mathrm{p}<0.01$ ), whereas mortality rates in autumn-winter were negatively correlated with temperature $(\mathrm{r}=-0.49, \mathrm{n}=28, \mathrm{p}<0.01)$. For 2 reasons the latter relationship did not seriously affect the relationship between winter temperatures and annual mortality rates (Fig. 3b): (1) the contribution of autumn-winter mortality to annual mortality rates was minor (see above); and (2) there was some compensation of the higher mortality rates in cold winters, as subsequent spring-summer mortality rates tended to be lower after cold than after mild winters $(\mathrm{r}=0.28, \mathrm{n}=29, \mathrm{p}=$ $0.15)$. Thus, the net influence of temperature on annual survival in Macoma balthica was significantly nega-

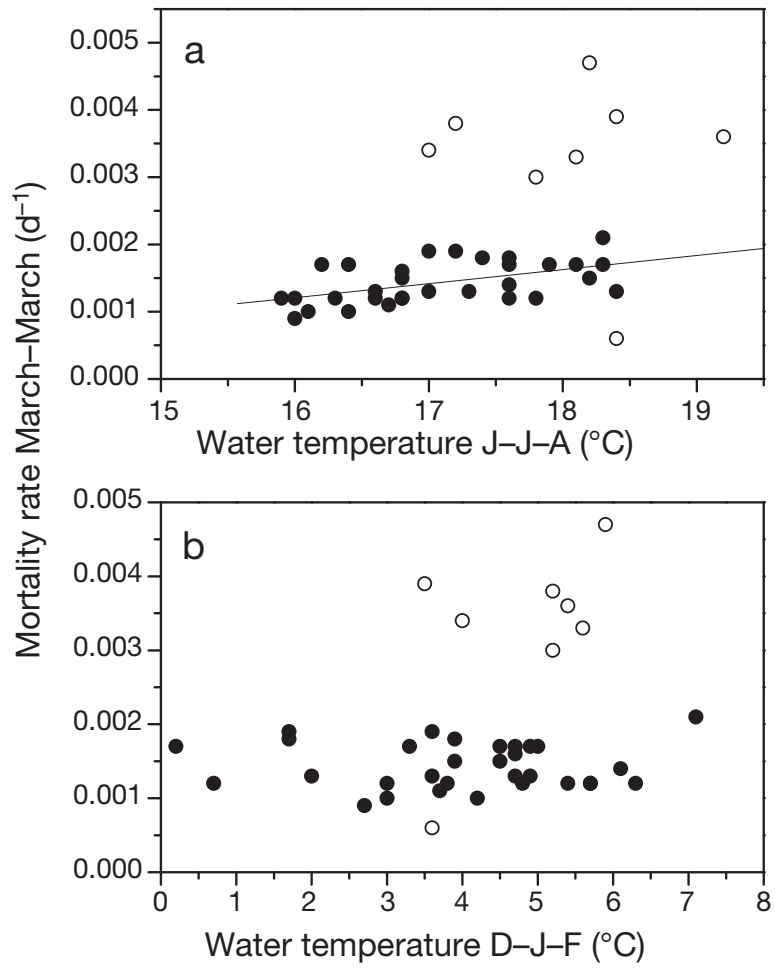

Fig. 3. Macoma balthica. Annual mortality rates (expressed as mean instantaneous daily rates, $\mathrm{d}^{-1}$ ) based on numerical densities in March of $>1$ yr olds over 39 yr (1969-2007) at 15 fixed sampling stations on Balgzand in relation to (a) mean summer (Jun-Aug) and (b) mean winter (Dec-Feb) temperature in that year. (O): outliers, 1999-2006 with enhanced and 1976-1977 with reduced mortality. The only statistically significant correlation was between mortality and summer temperatures for the group of $31 \mathrm{yr}(\bullet)$ with a best linear fit shown by a line in (a): mortality $=-0.0021+0.00021 \times$ summer temperature $(\mathrm{r}=0.51, \mathrm{n}=31, \mathrm{p}=0.003)$

tive in warm summers whereas no significant net influence of winter temperatures was observed.

\section{Weight gain and loss}

Mean individual weight changes in the MarchAugust periods (which include the annual growing seasons) were invariably positive and varied by a factor of $\sim 3$ (Fig. 1e). These seasonal weight gains between March and August were on average higher in years with cold than with warm growing seasons (Fig. 4).

Throughout the remainder of the year, Macoma balthica individuals generally lost weight in all months between July and March (Hummel 1985b, Dekker \& Beukema 2007). These weight losses were more substantial in half-year periods including a mild winter than those including a cold winter (Fig. 2b), as also 


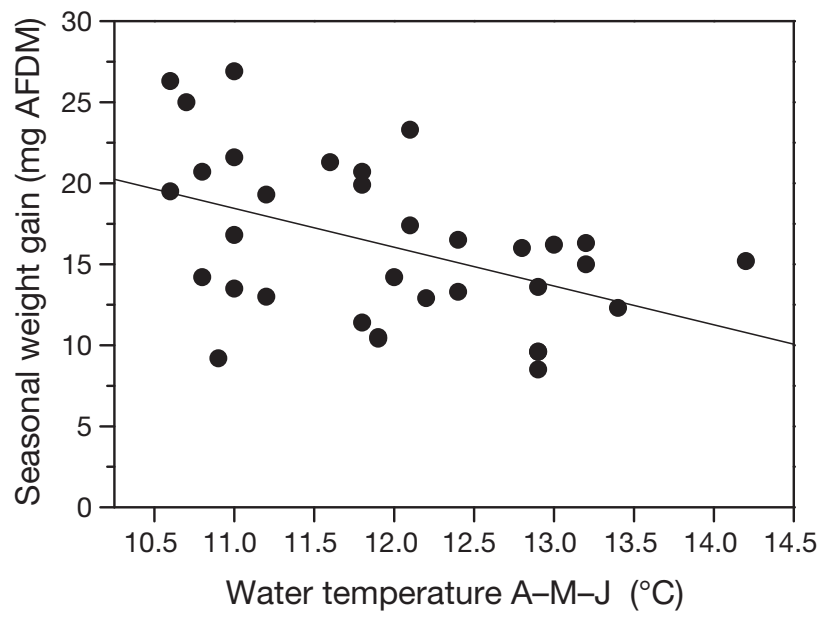

Fig. 4. Macoma balthica. Relationship between mean water temperature during the growing season (Apr-Jun, ${ }^{\circ} \mathrm{C}$ ) and mean individual weight gain of soft body parts between March and August in 1 yr olds, in mg ash-free dry mass (AFDM). Best linear fit: weight gain $=44.8-2.4 \times$ temperature $(\mathrm{r}=-0.46, \mathrm{n}=34, \mathrm{p}<0.01)$

observed by Zwarts (1991) and Honkoop \& Beukema (1997). Losses in $\sim 1.5$ yr old $M$. balthica significantly increased from $\sim 15 \%$ in half-year periods including a cold winter to $\sim 35 \%$ in those periods including a mild winter. In older age groups seasonal losses were even higher (Dekker \& Beukema 2007). These weight losses are conveniently expressed as changes in BMI, because length growth is negligible during these halfyear periods (Beukema et al. 1985, their Fig. 7).

\section{DISCUSSION}

\section{Effects of temperature on population dynamics and weights}

The Balgzand tidal flat Macoma balthica population ( $1000 \mathrm{~km}$ north from the warm southern edge of its European range) is certainly not marginal. In the Wadden Sea, $M$. balthica is a common species with mostly high values for numerical density, biomass, and production (Dekker \& Beukema 2007), showing growth rates close to the maximum values observed in Europe (Beukema \& Meehan 1985, their Fig. 3). Nevertheless, it was found to suffer in a number of different ways from above-average seasonal temperatures in this area.

Results from the present long-term study revealed several population-size reducing responses to warmer than average seasons. These negative reactions included lower recruitment after mild than after cold winter-spring seasons (Fig. 2a) and lower survival in years including a hot rather than a cool summer (Fig. 3a). Further, lower proportions of juveniles migrated (by means of thread-drifting; Beukema \& De Vlas 1989) from nearshore areas to more favourable offshore locations (Beukema 1993) in mild than in cold winters (Hiddink \& Wolff 2002, Beukema \& Dekker 2003).

Results from the long-term data series in the Wadden Sea also revealed temperature influences on seasonal changes in individual weights. Weight was negatively affected by higher than average temperatures in 2 ways: seasonal weight gains were lower in warm than in cool growing seasons (Fig. 4) and seasonal weight losses were more substantial in mild than in cold winters (Fig. 2b).

For bivalve populations living near the edge of their range, temperature may generally affect multiple ecological and physiological processes. In the southern Atlantic scallop Psychrochlamys patagonica, Gutiérrez et al. (2008) found that the equatorial limit of its range could be ascribed mainly to abrupt temperature changes in its environment causing poor recruitment, high mortality, as well as low growth rates.

\section{Phenology}

In the Wadden Sea, annual growing seasons of Macoma balthica are short, typically not longer than 3 or 4 mo (Beukema \& De Bruin 1977, Dekker \& Beukema 2007). Usually, annual growth begins slowly in March. At that time, new growth is discernable only in spat-sized individuals. With increasing winter temperatures, this start has shifted to earlier dates: around 1 March after a mild winter and a few weeks later after a cold winter (Beukema et al. 1985). The ends of the growing season also depend on temperature, again with earlier dates (in July) at higher temperatures (Beukema et al. 1985). Both March and July water temperatures showed increasing trends between 1970 and 2007 (March: $0.05^{\circ} \mathrm{C} \mathrm{yr}^{-1}, \mathrm{r}=0.37, \mathrm{p}=0.02$; July: $0.03^{\circ} \mathrm{C}$ $\left.\mathrm{yr}^{-1}, \mathrm{r}=0.28, \mathrm{p}=0.08\right)$. Thus, during the past 4 decades, both the start and the end of the growing season have shifted by a few weeks to earlier dates, but the length of the growing season may not have substantially changed. Because there is no evidence that the timing of phytoplankton blooming depends on spring temperatures nor that phytoplankton peaks have shifted to earlier dates within the last 3 decades of the 20th century (Philippart et al. 2003), it is difficult to determine whether the shift of the growing season of $M$. balthica to a somewhat earlier period in spring would lead to better or lower annual growth of this species in the Wadden Sea.

At lower latitudes, temperatures tend to be higher throughout the year. Earlier starts of the growing season of Macoma balthica would therefore be expected and have been found-in the Seine estuary, some 
$500 \mathrm{~km}$ south of the Wadden Sea, growth began in February (Beukema \& Desprez 1986).

Spawning is triggered by water temperature in early spring, $\sim 10^{\circ} \mathrm{C}$ according to De Wilde (1975) and a few ${ }^{\circ} \mathrm{C}$ lower according to Drent \& Luttikhuizen (2004). For the last 3 decades of the 20th century, these threshold values were reached at significantly increasingly earlier dates (Philippart et al. 2003). Since the mid-1980s, spawning start dates have become earlier at a rate of $\sim 1 \mathrm{~d} \mathrm{yr}^{-1}$.

Drent (2004) compiled data on the time of annual spawning in west-European Macoma balthica populations and did not find a clear latitudinal trend in their spawning season; in fact, spawning appeared to take place across most locations between March and April. However, at the southernmost locations, i.e. in the Gironde estuary (where winter water temperatures scarcely decline below $8^{\circ} \mathrm{C}$ ), spawning has been observed in January and February (Bachelet 1986, Drent 2004).

\section{Range shifts}

Half a century ago, the southernmost European populations of Macoma balthica were located in the Spanish part of the Bay of Biscay at $\sim 43^{\circ} 20^{\prime} \mathrm{N}$, but more recent reports of its occurrence appear to be lacking (Jansen et al. 2007a). Searching in estuaries south of nearby Arcachon Bay $\left(\sim 44^{\circ} 40^{\prime} \mathrm{N}\right)$ did not yield any specimens (G. Bachelet pers. comm.). Within Arcachon Bay, the species was still present in good numbers at several places in the 1980s (Bachelet et al. 1990); however, in the early 2000s, Blanchet (2004) found no specimens, despite intensive sampling at almost 200 sites. In 2006, a single specimen was occasionally found in the easternmost part of the bay (G. Bachelet pers. comm.). The present southern limit of regular occurrence of $M$. balthica in Europe appears to be the Gironde estuary, where the species has recently been found at several locations north of $\sim 45^{\circ} 20^{\prime} \mathrm{N}$, both in the intertidal and subtidal zones (G. Bachelet pers. comm.). Thus, a shift of several $100 \mathrm{~s}$ of $\mathrm{km}$ of its southern limit to the north appears to have recently taken place. Mean water temperatures in the area where the species disappeared are $\sim 1^{\circ} \mathrm{C}$ higher than within its present range, and maximum temperature differences may be even greater (Jansen et al. 2007a).

Within the Wadden Sea, the annual low-temperature stimulated migration of Macoma balthica spat in winter enhances numbers in low-intertidal or subtidal offshore areas at the expense of high-intertidal nearshore populations. Particularly in the subtidal and lowest intertidal flats of the Wadden Sea, this secondary recruitment in winter is more important than primary recruitment by larval settlement in late-spring. Thus, the final distribution pattern of adult $M$. balthica is largely affected by a winter-temperature related process involving migrations over distances of several $\mathrm{km}$. As a result of this migration, an enhanced proportion of adults can live in areas where their survival is better, growth is more rapid, and reproductive output is higher (Beukema 1993, Hiddink et al. 2002, van der Meer et al. 2003, Cardoso et al. 2007). Moreover, by moving to offshore areas these individuals avoid extreme temperatures. In shallow coastal marine and estuarine areas such as the Wadden Sea, summer temperatures are usually higher and winter temperatures lower than in nearby shelf seas such as the North Sea (De Vooys 1990, his Fig. 3). On hot summer days, temperatures at the sediment surface of the highest tidal flats within the southern half of the distribution area of $M$. balthica can reach $\sim 30^{\circ} \mathrm{C}$ during prolonged periods of emersion. This is so close to their lethal limits that they should avoid such areas either by moving to deeper waters or by burrowing into deeper layers of the sediment (as they do after the growing season; Zwarts \& Wanink 1993, De Goeij 2001).

Offshore migrations to deeper areas have been described for the Wadden Sea (see above) and the Westerschelde estuary in the SW of The Netherlands (Bouma et al. 2001), but (as far as we are aware) not for any area at a lower latitude. In 2 Tellina species, Wilson (1990) reports observations pointing to a shift of maximal abundance to deeper and more offshore zones in low latitude areas compared to high latitude areas.

\section{Mechanisms underlying temperature effects}

Understanding the processes underlying the influence of temperature on recruitment, mortality, and individual weight (and ultimately on the species' distribution and abundance) is challenging (Helmuth et al. 2006), but these processes are incompletely known. Effects of a warming climate may manifest either directly from physiological stress within individuals (acute effects, Pörtner 2001, chronic effects, Jansen et al. $2007 \mathrm{~b}$, present study) and/or indirectly from changed interrelationships with other species (such as predation and competition).

\section{Recruitment}

The observed reduced annual recruitment after warmer than average winter-spring seasons may have multiple causes acting at different life stages. Honkoop \& van der Meer (1997) reported that adult female Macoma balthica produce more eggs after cold than 
after mild winters. However, between-year variability in calculated total numbers of spawned eggs per $\mathrm{m}^{2}$ could explain only a meager $7 \%$ of variability in subsequent recruit densities (Honkoop et al. 1998). Therefore, processes acting after the egg stage may have contributed more decisively to the relationship between winter temperatures and recruitment.

Food supply for larval stages might be more favourable after cold than after mild winters. In the German Wadden Sea, higher spring phytoplankton biomass results from lower water temperatures in the preceding winter (Martens 2001, van Beusekom et al. 2009). On the other hand, shifts in spawning time to earlier dates in spring appear to lead to a poorer match between young larval stages of Macoma balthica and food availability, causing lower survival from egg to spat stage (Philippart et al. 2003).

A subsequent match may be of at least equal importance: that of the earliest benthic stage of Macoma balthica on tidal flats with the appearance of their main predator, the shrimp Crangon crangon. Shrimp abundance is not only higher but also peaks earlier on the Wadden Sea tidal flats after mild winters (Beukema 1992). The magnitude of predation by shrimp on early benthic stages of $M$. balthica contributes significantly to the latter's survival (Philippart et al. 2003) and final recruit densities in summer are higher after low shrimp densities on tidal flats in late spring (Beukema et al. 1998, Beukema \& Dekker 2005). Between-year variability in shrimp biomass on tidal flats in May explains $\sim 50 \%$ of the year-to-year variability in the magnitude of $M$. balthica recruitment as assessed in the subsequent summer (Beukema et al. 1998, their Fig. 9, Beukema \& Dekker 2005, their Table 4).

\section{Mortality}

The cause of the observed enhanced mortality rates in years (and particularly in spring-summer half-year periods) with a warm summer season is not clear. Low weight-at-length values lead to reduced survival (Beukema et al. 2001b). In summer, such condition values are relatively low in years with low growth (Beukema \& Cadée 1991) and growth is retarded when condition values at the start of the growing season are low (Beukema et al. 2001b). Such low condition values occur particularly by rapid weight loss in mild winters (Fig. 2b). Thus, the reduced survival in warm springsummer periods may be associated with the observed reduced growth rates in years with elevated spring temperatures (Fig. 4) and greater weight loss in mild winters (Fig. 2b).

Additionally, in the larval stage of Macoma balthica, survival is negatively related to temperature. Though growth rates increase with increasing temperature, mortality rates increase faster, and the resulting mortality between egg and metamorphosis increases with temperature (Drent 2002).

\section{Migration}

Low water temperatures stimulate floating behaviour in spat (Sörlin 1988). In tidal streams of the Wadden Sea, Hiddink \& Wolff (2002) caught more drifting spat by plankton nets in winter in colder water. The higher spat concentrations in cold winters may also be associated with a higher viscosity of cold water, causing slower sinking of spat, which would result in longer distances of transportation by tidal currents and wider distribution (Beukema \& De Vlas 1989). Thus both a low-temperature stimulus as well as better transportation by cold water may contribute to the observation by Beukema \& Dekker (2003) that higher proportions of Macoma balthica spat populations migrate in cold winters.

\section{Weight changes and energy balance}

Changes in weights of soft parts reflect a net result of the balance of energy gain by food intake and energy loss by respiration. The 2 processes are governed by the interplay of ambient temperatures and food concentrations. The short annual periods of net energy gain in Wadden Sea populations coincide with the short periods (April-June) of high concentrations of chlorophyll-containing material (Hummel 1985a); in particular, diatom concentrations during the growing season appear to be decisive (Beukema \& Cadée 1991). The growing period starts when temperatures have risen to $\sim 5^{\circ} \mathrm{C}$ in late winter (Beukema et al. 1985), and earlier when phytoplankton concentrations are well above their long-term average (Beukema \& Cadée 1996). In the Wadden Sea, the growing season ends in mid-summer when temperatures exceed $\sim 16^{\circ} \mathrm{C}$ (Beukema et al. 1985). Phytoplankton concentrations are then low and Macoma balthica reduce their activity and stop active feeding (Hummel 1985b).

A reduction of metabolic activity is a general and necessary response of an ectotherm to suboptimal conditions (Hoffmann 1976, Branch et al. 1988, Hawkins 1995). Macoma balthica shows a great capacity to reduce its metabolic activity at elevated temperatures (Jansen et al. 2007b). When submerged, maintenance costs may become strongly reduced, and when exposed to air during low tide, $M$. balthica may utilize anaerobic metabolic pathways to minimize its glycolytic flux (Carroll \& Wells 1995, Hand \& Hardewig 
1996). Seasonal variation in anaerobic metabolic endproducts shows that more alanine is accumulated in individuals from low latitudes during summer (Kube et al. 2007). Despite this extensive plasticity, weight gain turns to weight loss and this reversal takes place earlier in warm summers (Beukema et al. 1985). Near the southern border of their range, $M$. balthica cannot sufficiently reduce their energy use and thus cannot reach sufficiently high weight-at-length (BMI) levels at the end of the growing season to survive the subsequent weight-loss season, as BMI values decline in the course of the latter season to values $<5 \mathrm{mg} \mathrm{cm}^{-3}$ and most of the animals die (Hummel et al. 2000). Transplanted beyond the southern border of their range, they appear to be unable to control energy expenditure and rapid weight loss was observed (Jansen et al. 2007a). Apparently, $M$. balthica become moribund at low BMI levels. In the Wadden Sea, such low BMI values are rarely observed, but if so, they lead to reduced survival (Beukema et al. 2001b).

A lower BMI threshold appears to exist not only for survival but also for reproduction. It was assessed at $5.6 \mathrm{mg} \mathrm{cm}^{-3}$ by Honkoop \& van der Meer (1997). Recruitment is a prime factor governing the long-term abundance and production in tidal-flat bivalve species such as Macoma balthica (van der Meer et al. 2001, Dekker \& Beukema 2007). Consistently low recruitment success (Fig. 1c) might be a major factor in the recent declining trend in M. balthica abundance (Fig. 1b) in the western Wadden Sea.

\section{CONCLUSIONS}

In summary, relatively high seasonal temperatures negatively affect Macoma balthica population processes (such as survival and reproduction) via effects on the bivalve's energy balance, resulting in low BMI (condition) values leading to subsequently reduced survival and reproductive output. Therefore, we conclude that the outcome of the energy balance (as expressed in BMI values) may be crucial not only for individual weight changes, but also by its decisive effect on both mortality and reproduction. The higher the ambient temperatures, the shorter are the annual periods of favourable combinations of temperature and food supply and the lower are the chances to reach sufficiently high weight-at-length values to survive and reproduce. In addition, elevated winter temperatures in the Wadden Sea may lead to reduced recruitment by more severe shrimp predation on postlarvae and slower growth by lower phytoplankton concentrations.

Acknowledgements. The present study is part of a long-term monitoring program on macrozoobenthos in the Wadden Sea executed by NIOZ and financially supported by the Dutch Ministry of Transport, Public Works and Water Management, Water Service (RWS-Waterdienst). We thank G. Bachelet (Université Bordeaux 1) for placing detailed data on Macoma balthica distribution in SW France at our disposal.

\section{LITERATURE CITED}

Bachelet G (1986) Recruitment and year-to-year variability in a population of Macoma balthica (L.). Hydrobiologia 142: 233-248

Bachelet G, Labourg PJ, Madani I (1990) Nouvelles signalisations de Mollusques (Prosobranches et Bivalves) dans le Bassin d'Arcachon. Cah Biol Mar 31:87-92

> Barry JP, Baxter CH, Sagarin RD, Gilman SE (1995) Climaterelated, long-term faunal changes in a California rocky intertidal community. Science 267:672-675

Beukema JJ (1992) Dynamics of juvenile shrimp Crangon crangon in a tidal-flat nursery of the Wadden Sea after mild and cold winters. Mar Ecol Prog Ser 83:157-165

Beukema JJ (1993) Successive changes in distribution patterns as an adaptive strategy in the bivalve Macoma balthica (L.) in the Wadden Sea. Helgol Wiss Meeresunters 47:287-304

Beukema JJ, Cadée GC (1991) Growth rates of the bivalve Macoma balthica in the Wadden Sea during a period of eutrophication: relationships with concentrations of pelagic diatoms and flagellates. Mar Ecol Prog Ser 68:249-256

Beukema JJ, Cadée GC (1996) Consequences of the sudden removal of nearly all mussels and cockles from the Dutch Wadden Sea. PSZN I: Mar Ecol 17:279-289

Beukema JJ, Cadée GC (1997) Local differences on macrozoobenthic response to enhanced food supply caused by mild eutrophication in a Wadden Sea area: food is only locally a limiting factor. Limnol Oceanogr 42:1424-1435

> Beukema JJ, De Bruin W (1977) Seasonal changes in dry weight and chemical composition of the soft parts of the tellinid bivalve Macoma balthica in the Dutch Wadden Sea. Neth J Sea Res 11:42-55

> Beukema JJ, Dekker R (2003) Redistribution of spat-sized Macoma balthica in the Wadden Sea in cold and mild winters. Mar Ecol Prog Ser 265:117-122

Beukema JJ, Dekker R (2005) Decline of recruitment success in cockles and other bivalves in the Wadden Sea: possible role of climate change, predation on postlarvae and fisheries. Mar Ecol Prog Ser 287:149-167

> Beukema JJ, Desprez M (1986) Single and dual annual growing seasons in the tellinid bivalve Macoma balthica (L.). J Exp Mar Biol Ecol 102:35-45

Beukema JJ, De Vlas J (1989) Tidal-current transport of thread-drifting postlarval juveniles of the bivalve Macoma balthica from the Wadden Sea to the North Sea. Mar Ecol Prog Ser 52:193-200

Beukema JJ, Meehan BW (1985) Latitudinal variation in linear growth and other shell characteristics of Macoma balthica. Mar Biol 90:27-33

Beukema JJ, Knol E, Cadée GC (1985) Effects of temperature on the length of the annual growing season in the tellinid bivalve Macoma balthica (L.) living on tidal flats in the Dutch Wadden Sea. J Exp Mar Biol Ecol 90:129-144

Beukema JJ, Honkoop PJC, Dekker R (1998) Recruitment in Macoma balthica after mild and cold winters and its possible control by egg production and shrimp predation. Hydrobiologia 375/376:23-34

> Beukema JJ, Dekker R, Essink K, Michaelis H (2001a) Synchronized reproductive success of the main bivalve 
species in the Wadden Sea: causes and consequences. Mar Ecol Prog Ser 211:143-155

Beukema JJ, Drent J, Honkoop PJC (2001b) Maximizing lifetime egg production in a Wadden Sea population of the tellinid bivalve Macoma balthica: a trade-off between immediate and future reproductive outputs. Mar Ecol Prog Ser 209:119-129

Blanchet H (2004) Structure et fonctionnement des peuplements benthiques du Bassin d'Arcachon. PhD thesis, Université Bordeaux 1, Talence

Bouma H, De Vries PP, Duiker JMC, Herman PMJ, Wolff WJ (2001) Migration of the bivalve Macoma balthica on a highly dynamic tidal flat in the Westerschelde estuary, The Netherlands. Mar Ecol Prog Ser 224:157-170

Branch GM, Borchers P, Brown CR, Donnelly D (1988) Temperature and food as factors influencing oxygen consumption of intertidal organisms, particularly limpets. Am Zool 28:137-146

Cardoso JFMF, Witte JIJ, van der Veer HW (2007) Habitat related growth and reproductive investment in estuarine waters, illustrated for the tellinid bivalve Macoma balthica (L.) in the western Dutch Wadden Sea. Mar Biol 152: 1271-1282

Carroll L, Wells MG (1995) Strategies of anaerobiosis in New Zealand infaunal bivalves: adaptations to environmental and functional hypoxia. N Z J Mar Freshw Res 29:137-146

De Goeij P (2001) Burying depth as a trade-off in the bivalve Macoma balthica. PhD dissertation, State University Groningen

De Vooys CGN (1990) Expected biological effects of longterm changes in temperatures on benthic ecosystems in coastal waters around The Netherlands. In: Beukema JJ, Wolff WJ, Brouns JJWM (eds) Expected effects of climatic change on marine coastal ecosystems. Kluwer Academic Publishers, Dordrecht, p 77-82

De Wilde PAWJ (1975) Influence of temperature on behaviour, energy metabolism and growth of Macoma balthica (L.). In: Barnes H (ed) Proc 9th Eur Mar Biol Symp, Oban, Scotland, 2-8 Oct 1974. Aberdeen University Press, Aberdeen, p 239-256

Dekker R, Beukema JJ (2007) Long-term and large-scale variability in productivity of the tellinid bivalve Macoma balthica on Wadden Sea tidal flats. Mar Ecol Prog Ser 337: 117-134

Dekker R, Waasdorp D (2008). Het macrozoobenthos op twaalf raaien in de Waddenzee en de Eems-Dollard in 2007. NIOZ Rapport 2008-5, Royal Neth Inst Sea Res (NIOZ), Texel

Drent J (2002) Temperature responses in larvae of Macoma balthica from a northerly and southerly population of the European distribution range. J Exp Mar Biol Ecol 275: $117-129$

Drent J (2004) The relative importance of temperature for growth and reproduction in an intertidal marine bivalve, Macoma balthica, along a latitudinal gradient. In: Drent J (ed) Life history variation of a marine bivalve (Macoma balthica) in a changing world. $\mathrm{PhD}$ thesis, State University Groningen, $\mathrm{p}$ 119-131

Drent J, Luttikhuizen PC (2004) Temporal and spatial variation in spawning of the bivalve Macoma balthica. In: Drent $\mathrm{J}$ (ed) Life history variation of a marine bivalve (Macoma balthica) in a changing world. $\mathrm{PhD}$ thesis, State University Groningen, p 81-93

Freitas V, Campos J, Fonds M, van der Veer HW (2007) Potential impact of temperature change on epibenthic predator-bivalve prey interactions in temperate estuaries. J Therm Biol 32:328-340
Gutiérrez NL, Martínez A, Defeo O (2008) Identifying environmental constraints at the edge of a species' range: scallop Psychrochlamys patagonica in the SW Atlantic Ocean. Mar Ecol Prog Ser 353:147-156

Hand SC, Hardewig I (1996) Downregulation of cellular metabolism during environmental stress: mechanisms and implications. Annu Rev Physiol 58:539-563

- Hawkins AJS (1995) Effects of temperature change on ectotherm metabolism and evolution: metabolic and physiological interrelations underlying the superiority of multi-locus heterozygotes in heterogeneous environments. J Therm Biol 20:23-33

> Helmuth B, Mieszkowska N, Moore P, Hawkins SJ (2006) Living on the edge of two changing worlds: forecasting the responses of rocky intertidal ecosystems to climate change. Annu Rev Ecol Evol Syst 37:373-404

Hiddink JG, Wolff WJ (2002) Changes in distribution and decrease in numbers during migration of the bivalve Macoma balthica. Mar Ecol Prog Ser 233:117-130

> Hiddink JG, Marijnissen SAE, Troost K, Wolff WJ (2002) Predation on 0-group and older year classes of the bivalve Macoma balthica: interaction of size selection and intertidal distribution of epibenthic predators. J Exp Mar Biol Ecol 269:223-248

Hoffmann KH (1976) Catalytic efficiency and structural properties of invertebrate muscle pyruvate kinases: correlation with body temperature and oxygen consumption rates. J Comp Physiol B 110:185-195

> Honkoop PJC, Beukema JJ (1997) Loss of body mass in winter in three intertidal bivalve species: an experimental and observational study of the interacting effects between water temperature, feeding time and feeding behaviour. J Exp Mar Biol Ecol 212:277-297

> Honkoop PJC, van der Meer J (1997) Reproductive output of Macoma balthica populations in relation to wintertemperature and intertidal-height mediated changes of body mass. Mar Ecol Prog Ser 149:155-162

> Honkoop PJC, van der Meer J, Beukema JJ, Kwast D (1998) Does temperature-influenced egg production predict the recruitment in the bivalve Macoma balthica? Mar Ecol Prog Ser 164:229-235

Houghton JT (ed) (2001) Climate change 2001: the scientific basis. Cambridge University Press, Cambridge

> Hummel H (1985a) Food intake of Macoma balthica (Mollusca) in relation to seasonal changes in its potential food on a tidal flat in the Dutch Wadden Sea. Neth J Sea Res 19:52-76

> Hummel H (1985b) An energy budget for a Macoma balthica (Mollusca) population living on a tidal flat in the Dutch Wadden Sea. Neth J Sea Res 19:84-92

- Hummel H, Bogaards RH, Bachelet G, Caron F, Sola JC, Amiard-Triquet C (2000) The respiratory performance and survival of the bivalve Macoma balthica (L.) at the southern limit of its distribution area: a translocation experiment. J Exp Mar Biol Ecol 251:85-102

IPCC (2007) Climate change 2007: the physical basis. Cambridge University Press, Cambridge

Jansen JM, Pronker AE, Wendelaar Bonga S, Hummel H (2007a) Macoma balthica in Spain, a few decades back in history. J Exp Mar Biol Ecol 344:161-169

> Jansen JM, Pronker AE, Kube S, Sokolowski A and others (2007b) Geographic and seasonal patterns and limits on the adaptive response to temperature of European Mytilus spp. and Macoma balthica populations. Oecologia 154: $23-34$

> Kube S, Sokolowski A, Jansen JM, Schiedek D (2007) Seasonal variability of free amino acids in two marine 
bivalves, Macoma balthica and Mytilus spp., in relation to environmental and physiological factors. Comp Biochem Physiol A 147:1015-1027

Martens P (2001) Effects of the severe winter 1995/96 on the biological oceanography of the Sylt-Rømø tidal basin. Helgol Mar Res 55:166-169

> Nikula R, Strelkov P, Väinölä R (2007) Diversity and transArctic invasion history of mitochondrial lineages in the North Atlantic Macoma balthica complex (Bivalvia: Tellinidae). Evolution 61:928-941

Philippart CJM, van Aken HM, Beukema JJ, Bos OG, Cadée GC, Dekker R (2003) Climate-related changes in recruitment of the bivalve Macoma balthica. Limnol Oceanogr 48:2171-2185

Pörtner HO (2001) Climate change and temperature-dependent biogeography: oxygen limitation of thermal tolerance in animals. Naturwissenschaften 88:137-146

Root TL, Price JT, Hall KR, Schneider SH, Rosenzweig C, Pounds JA (2003) Fingerprints of global warming on wild animals and plants. Nature 421:57-60

Sörlin T (1988) Floating behaviour in the tellinid bivalve Macoma balthica (L.). Oecologia 77:273-277

Strasser M, Dekker R, Essink K, Günther CP and others (2003) How predictable is high bivalve recruitment in the Wadden Sea after a severe winter? J Sea Res 49:47-57

Väinölä R (2003) Repeated trans-Arctic invasions in littoral bivalves: molecular zoogeography of the Macoma balthica complex. Mar Biol 143:935-946

van Aken HM (2008) Variability of the water temperature in the western Wadden Sea on tidal to centennial time

Editorial responsibility: Charles Peterson,

Morehead City, North Carolina, USA scales. J Sea Res 60:227-234

van Beusekom JEE, Loebl M, Martens P (2009) Distant riverine nutrient supply and local temperature drive the longterm phytoplankton development in a temperate coastal basin. J Sea Res 61:26-33

van der Meer J, Beukema JJ, Dekker R (2001) Long-term variability in secondary production of an intertidal bivalve population is primarily a matter of recruitment variability. J Anim Ecol 70:159-169

van der Meer J, Beukema JJ, Dekker R (2003) Large spatial variability in lifetime egg production on an intertidal Baltic tellin (Macoma balthica) population. Helgol Mar Res 56:274-278

> van der Veer HW, Cardoso JFMF, van der Meer J (2006) The estimation of DEB parameters for various Northeast Atlantic bivalve species. J Sea Res 56:107-124

Wilson JG (1990) Effects of temperature changes on infaunal circalittoral bivalves, particularly $T$. tenuis and $T$. fabula. In: Beukema JJ, Wolff WJ, Brouns JJWM (eds) Expected effects of climatic change on marine coastal ecosystems. Kluwer Academic Publishers, Dordrecht, p 93-97

Z Zwarts L (1991) Seasonal variation in body weight of the bivalves Macoma balthica, Scrobicularia plana, Mya arenaria and Cerastoderma edule in the Dutch Wadden Sea. Neth J Sea Res 28:231-245

Zwarts L, Wanink JH (1993) How the food supply harvestable by waders in the Wadden Sea depends on the variation in energy density, body weight, biomass, burying depth and behaviour of tidal-flat invertebrates. Neth J Sea Res 31: $441-476$

Submitted: August 18, 2008; Accepted: January 31, 2009

Proofs received from author(s): May 18, 2009 